\title{
Assessment of the exposure level to saltwater intrusion in the context of climate change at Dong Nai province to 2030
}

- Ngoc Tuan Le

University of Science, VNU-HCM

- Xuan Hoang Tran

Institute of Meteorology Hydrology Oceanology and Environment

(Received on $6^{\text {th }}$ June 2016, accepted on $30^{\text {th }}$ October 2017)

\section{ABSTRACT}

The study aimed to assess the exposure level (E) to saltwater intrusion (SI) in the context of climate change (CC) at Dong Nai province to 2030. The results serve to assess vulnerability due to this phenomenon. The research scope included 57 wards in Bien Hoa city, Long Thanh, and Nhon Trach districts where have been facing to SI. Results showed that: (i) The high exposure area (E $\geq 75)$ : near Long Tau, Dong Tranh, Go Gia rivers and Thi Vai river downstream; (ii) The medium - high exposure area $(50 \leq E<75)$ : Thi Vai river upstream, Nha Be, and Long Tau rivers; (iii) The medium - low exposure area $(25$ $<E<50$ ): Dong Nai river above the confluence with Saigon river about $10 \mathrm{~km}$ and the area between Dong Mon and Thi Vai rivers; (iv) The low exposure area $(E \leq 25)$ : the entire of Bien Hoa city, a part of Long Thanh district located near Buong river, part 4 of Dong Nai river, and Thi Vai river upstream. The exposure level tends to increase over time $(2020,2030)$ and under CC scenarios. The differences between the current $E$ and that in 2030 are relatively small: 8.6, 1.96, and 2.71 in Bien Hoa, Long Thanh, and Nhon Trach, respectively. Thus, effects of climate change and sea level rise to the exposure level to SI are not really clear in the period 2014-2030. However, the increase in exposure index partly reflects the challenges for local governments and communities in response to SI and CC.

Keywords: saltwater intrusion, climate change, exposure index

\section{INTRODUCTION}

In the context of climate change (CC) is increasingly going strong, rivers' flow have been greatly influenced, indirectly affecting the saltwater intrusion (SI), thereby, altering water quality, affecting most of relevant activities in the riparian areas. Recently, many studies on $\mathrm{CC}$ consider SI as one of the most concern issues, especially in the estuaries and coastal areas [1-5]

Dong Nai province is in Dong Nai - Saigon River basin, despite the landlocked area (the nearest point from the sea about $9 \mathrm{~km}$ ), but with the characteristics of water reserve distribution (approximately $20 \%$ in the dry season ) and a semi-diurnal tide, rivers here are still at the high risk of SI. In recent years (monitoring data from 2007 to 2014), the salinization at Dong Nai province was negatively changed, salinity had increased significantly, especially from March to May. Thus, the SI at Dong Nai province is increasingly serious and should be concerned. Many studies on SI were carried out in downstream Dong Nai River [6-9], however, mostly focused on assessing salinization current, simulating and warning, etc. In other words, the vulnerability to SI in the context of CC have not been forecasted and fully assessed yet. 
It is very important to assess completely vulnerability to $\mathrm{SI}$ in the context of $\mathrm{CC}$ of different regions or sectors -to be considered in the relationship among the level of exposure (E), sensitivity (S) and adaptive capacity (AC). That provides a basis for planning suitable policies, strategies, and coping measures in each specific condition, contributes to minimize risks, and ensures the sustainable development of concerned socio-economic sectors. Accordingly, this study aims to evaluate the exposure level to SI in the context of CC at Dong Nai till 2030 by the index method, detailed to communes /wards in the investigated areas (Bien Hoa city, Long Thanh and Nhon Trach districts), serving the vulnerability assessment to SI in the context of CC.

\section{METHODS}

Index method

Index method was applied to quantify the exposure level of the SI with criteria such as highest salinity, salinity fluctuation, salinity duration, etc. E index was calculated by the formula: $E=\sum_{i-1}^{n}\left(E_{i} * w_{i}\right)(1)$, where

$\mathrm{E}_{\mathrm{i}}$ : the value of standardized $\mathrm{E}_{\mathrm{i}}$;

$\mathrm{w}_{\mathrm{i}}$ : priority weight of respective $\mathrm{E}_{\mathrm{i}}$

The exposure levels to SI in the context of $\mathrm{CC}$ were devided into 4 levels (Table 1) as a basis for comparison and evaluation of $\mathrm{E}$ among considered communes/wards.

Table 1. Assessment scale of exposure level

\begin{tabular}{|c|c|l|l|c|}
\hline Value & \multicolumn{1}{|c|}{$\mathbf{0 - 2 5}$} & \multicolumn{1}{|c|}{$\mathbf{2 5 - 5 0}$} & \multicolumn{1}{|c|}{$\mathbf{5 0 - 7 5}$} & $\mathbf{7 5 - 1 0 0}$ \\
\hline Describe & Low exposure & $\begin{array}{l}\text { Medium - low } \\
\text { exposure }\end{array}$ & $\begin{array}{l}\text { Medium - high } \\
\text { exposure }\end{array}$ & High exposure \\
\hline
\end{tabular}

\section{Data process method}

This method was used to analyse salinity simulation results, and then process concerned criteria: the highest salinity, the lowest salinity, salinity fluctuation, salinity duration, etc.

\section{Spatial interpolation method}

From the calculated results of salinity, this method was applied to calculate exposure levels to SI for different investigated areas. Inverse Distance to a Power gridding method and Surfer 10.0 were chosen. Fixed-search radius of $30-60$ $\mathrm{km}$ was applied. The barrier was the boundary of river basins.

\section{Professional adjustment}

30 experts in the field of environment, hydrology, water resources, etc. from 17 prestigious universities and institutes - who have knowledge and experience on CC, SI, and investigated area were consulted to determine indicators and respective weights representing exposure levels to SI at Dong Nai province.
The analytic hierarchy process - AHP

AHP method was used (in conjunction with professional adjustment) to calculate weights of indicators. Consistency was checked via Consistency Ratio (CR): $R=\frac{C I}{R I} \quad$ (2); where CI is consistency index: $C I=\frac{\lambda_{\max }-n}{n-1}$ (3); $\lambda_{\max }=$ $\lambda_{\max }=\frac{1}{n} \cdot \frac{\sum_{j=1}^{n} a_{i j} \cdot w_{j}}{w_{1}}(4) ; \mathrm{a}_{\mathrm{ij}}$ : the priority value of

variable in comparison matrix, $\mathrm{w}_{\mathrm{j}}$ : weight of the $\mathrm{j}$ variable, $\mathrm{n}$ : the number of variables; $\mathrm{RI}$ is random index, ranged from 0.58 to 1.49 corresponding to the number of variables from 3 to 10 . Consistency is assured when $\mathrm{CR} \leq 10 \%$. Results of professional adjustment was synthesized by multiplication average method.

\section{Standardized method}

The variables have different units and proportions, accordingly, it should be standardized (from $0-100$ ) before calculating. In this study, based on the interpolation results

\section{Trang 256}


(raster), the standardization was carried out by ArcGIS 10.2 using the tool Raster Calculator.

The highest salinity in a year: (in the range of 0-33\% in the calculated area) was standardized according to the salty scale of Karpevits: salinity from $0-1 \%$, 1-4 \%o, 4-18\%, and 18-33\% were standardized to $0-25$ points, $25-50$ points, 50-75 points, and 75-100 points, respectively.

Salinity fluctuation of the saltiest month: (in the range of 0-28\%) was standardized as follows: E.dd = Salinity fluctuation of the saltiest month (\%o) / the highest salinity (\%o* 100 .

Rate if salinity duration (above 1 and $4 \%$ ): (in the range of $0-100 \%$ ) was also standardized to 0-100 points.

\section{GIS method}

This method was used to exploit the data, perform calculations (standardize and calculate synthetic index), mapping, show data after being processed in order to visualize the calculation results. ArcGIS 10.2 and Map Info 11.0 were used.

\section{Inherited method}

The study inherits simulation results of SI in the context of CC at Dong Nai province [10]. Accordingly, the exposure indicators were statistically analysed include:

The highest salinity of a year: the highest salinity at each calculated node.

Salinity fluctuation of the saltiest month: was calculated by the difference between the highest and the lowest salinity in April.
Salinity duration (above 1 and $4 \%$ ): rate of time that salinity was above 1 and $4 \%$ in the dry season (from $05^{\text {th }}$ Jan to $30^{\text {th }}$ May) with a total simulation time of 3480 hours.

The output nodes of calculation results used to calculate exposure index are shown in Fig. 1

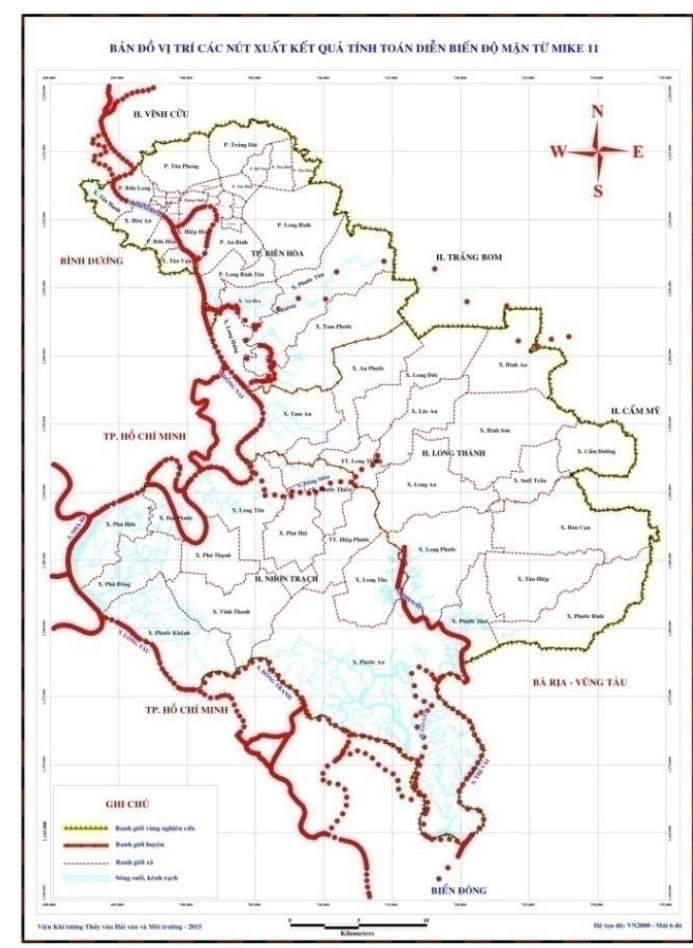

Fig. 1. Map of output notes of simulation results

\section{RESULTS}

\section{Indicators and weights}

By professional adjustment method and AHP, indicators for assessing exposure levels to $\mathrm{SI}$ in the context of $\mathrm{CC}$ were established as in Table 2.

Table 2. Indicators for assessing exposure levels to SI in the context of CC

\begin{tabular}{|c|l|c|c|c|}
\hline \multirow{2}{*}{ Group } & \multicolumn{1}{|c|}{ Indicator } & \multirow{2}{*}{ Code } & \multicolumn{2}{c|}{ Weights } \\
\cline { 4 - 5 } & & & Group & Component \\
\hline Salinity & The highest salinity of a year & E.dm & 0.424 & 0.424 \\
\hline Fluctuation & Salinity fluctuation of the saltiest month & E.dd & 0.253 & 0.253 \\
\hline \multirow{2}{*}{ Duration } & Duration of salinity above 1\%o & E.tg.1 & \multirow{2}{*}{0.323} & 0.332 \\
\cline { 2 - 4 } & Duration of salinity above 4 \%o & E.tg.2 & & 0.668 \\
\hline
\end{tabular}




\section{$\mathrm{E}$ index to $\mathrm{SI}$ in the context of $\mathrm{CC}$}

Component exposure index (E.dm, E.dd and E.tg) and total exposure index (E) were calculated for different scopes (district/city and ward/commune), periods (current, 2020, and 2030), and CC scenarios (low -B1, medium -B2, and high - A1FI emission scenarios).

\section{E index to salinity (E.dm)}

Calculating results, given in Fig. 2, showed that: currently, communes/wards significantly exposed to salinity include Phuoc Thai (Long Thanh district), Phuoc An, Long Tho, Phuoc Khanh, Vinh Thanh (Nhon Trach district), mainly located in Thi Vai, Dong Tranh, and Go Gia riversides. Phuoc An (Nhon Trach district) has the highest exposure level to salinity (92.07) while that in Cam Duong (Long Thanh district) is the lowest (0.1). In the period of 2020-2030, corresponding to $\mathrm{CC}$ scenarios, the highest exposure level to salinity tends to gradually increase, but not significantly.

\section{E index to salinity fluctuation (E.dd)}

Fig. 3 showed E index to salinity fluctuation (the saltiest month). It could be inferred that currently, 2/57 wards had high level of E.dd: Phu Huu (80.46) and Phuoc Khanh (83.56) (Nhon Trach district), located in Long Tau and
Dong Tranh river areas - the area with great salinity fluctuation. The area with lowest E.dd is Cam Duong (0.23) (Long Thanh district). In the period 2020-2030, the CC scenarios were taken into account, E.dd transformations would be complex in the investigated zone: relatively stable and tend to decrease at Nhon Trach district, rapidly increase at Bien Hoa city (highmedium level in 2030).

\section{E index to salinity duration (E.tg)}

E index to salinity duration was shown in Fig. 4. Currently, Bien Hoa city is hardly exposured with this index -consistent with the current situation of SI in this area. E.tg in Long Thanh district is relatively complex (the average E.tg is 23.96 - low level): 2/15 wards with high exposure (near Thi Vai river); 2/15 wards with medium-high exposure; the others with low exposure. At Nhon Trach district, average E.tg is 70.20 (medium-high level): the number of wards with low, medium-low, medium-high, and high exposure are 3/12, 2/12, 3/12, and 4/12, respectively. In the period 2020-2030, E.tg index tends to increase gradually over time and under CC scenarios. However, similar to E.dm index, the increase is relatively small. 


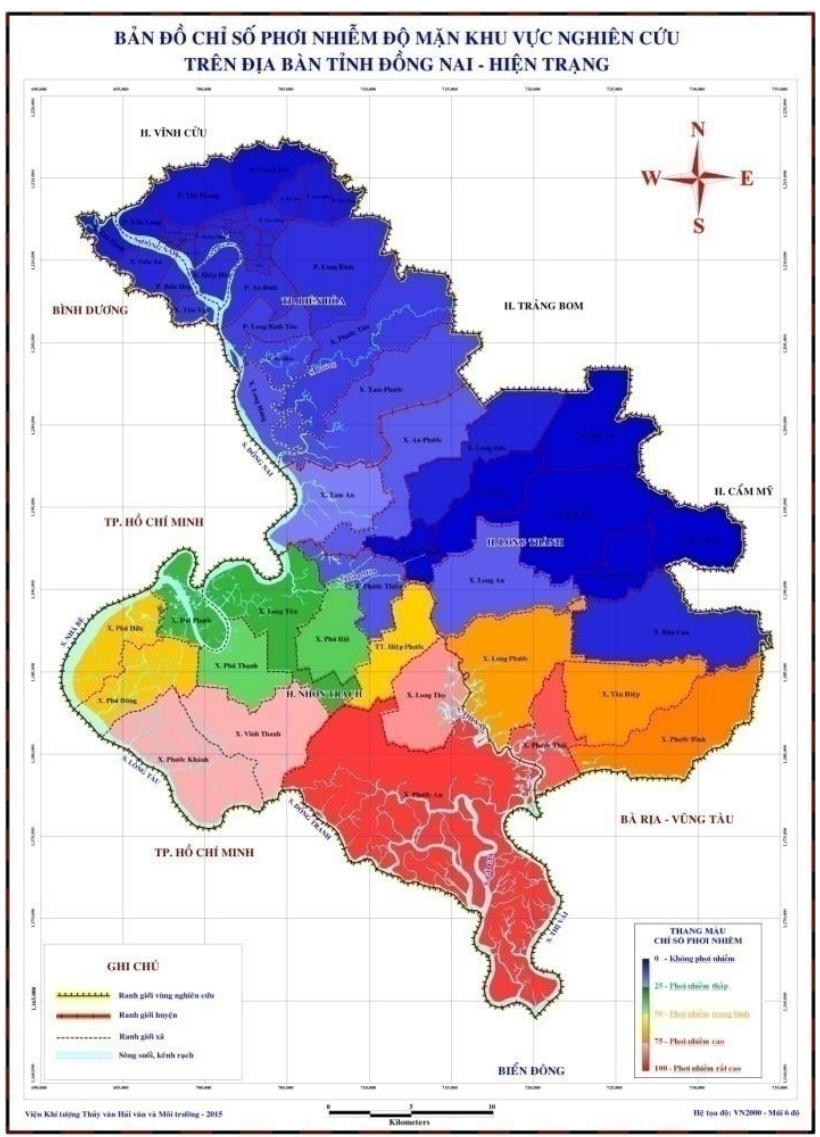

Fig. 2. Map of E.dm (currently)

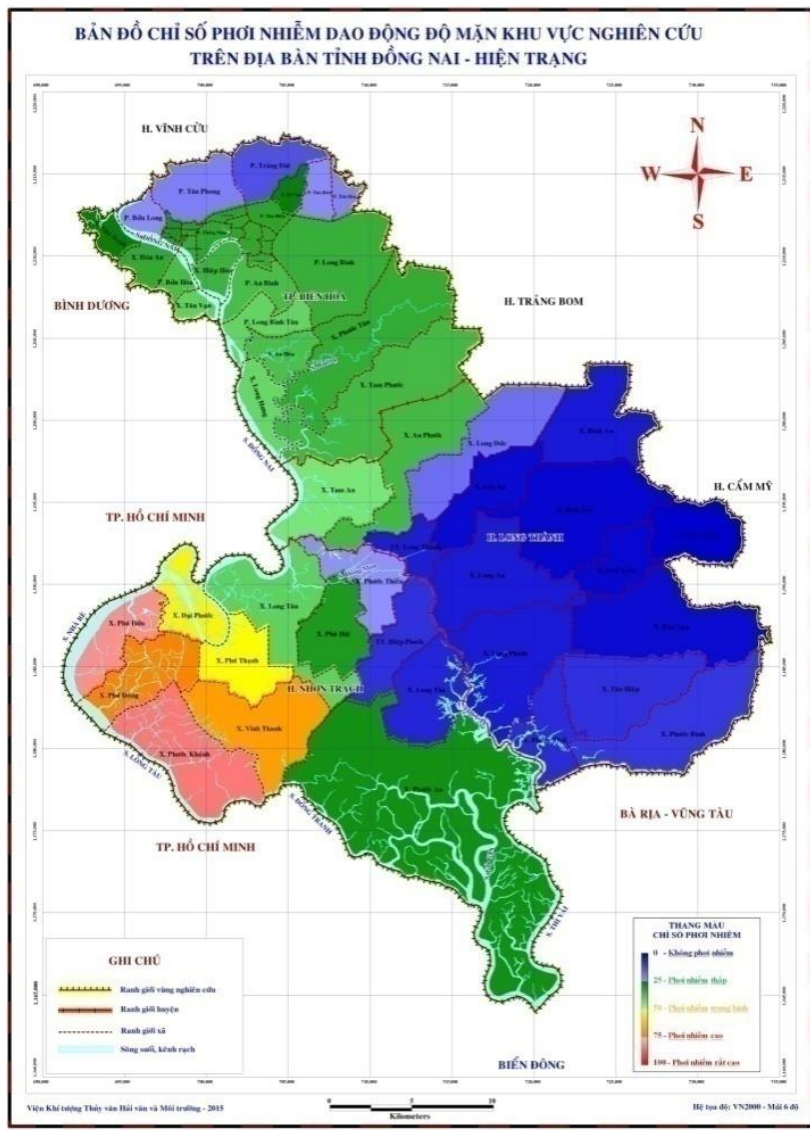

Fig. 3. Map of E.dd (currently)

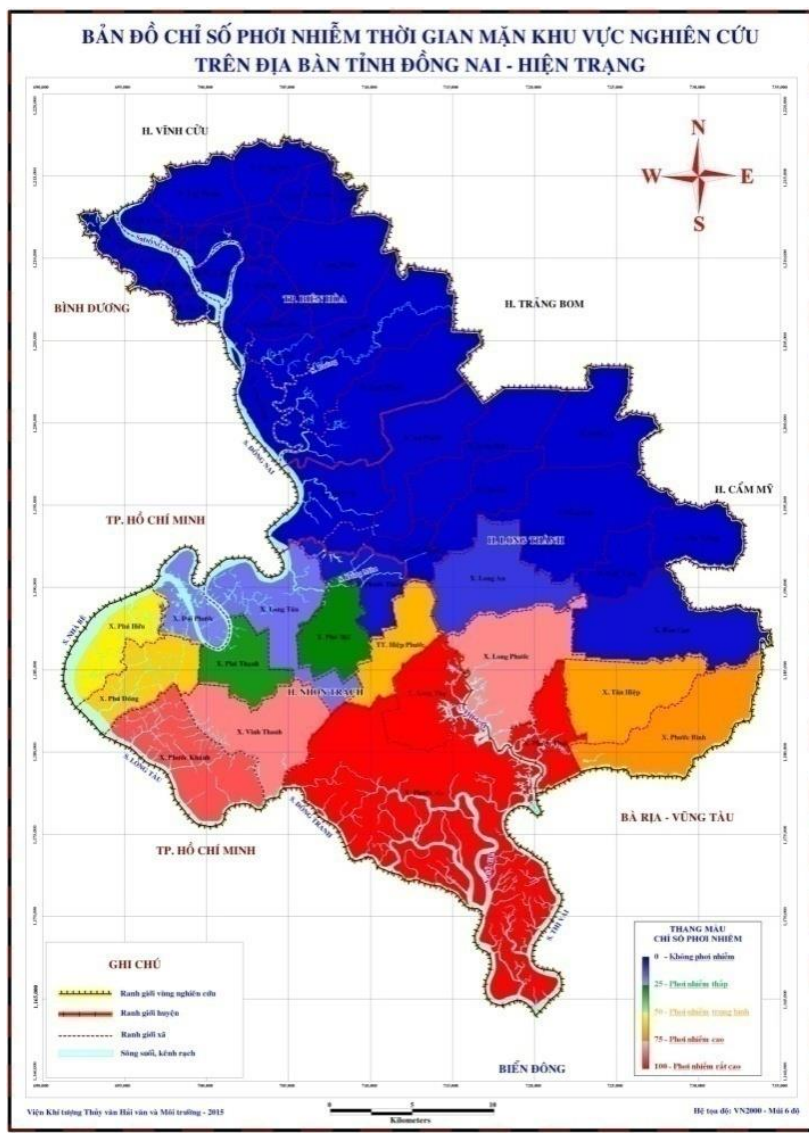

Fig. 4. Map of E.tg (currently) 


\section{The total exposure index to SI (E)}

Fig. 5 presents the current exposure index to SI at the investigated area. It could be divided into 4 regions.

The high exposure region (> 75): near Long Tau, Dong Tranh, Go Gia rivers, and Thi Vai river downstream -where have high salinity (the highest one is more than $25 \%$ ), large salinity fluctuation (15-28\%o), and long salinity duration (salinity is more than $1 \%$ in the whole calculated time); including Phuoc Khanh, Phuoc An, Vinh Thanh (Nhon Trach district).

The medium-high exposure region (50-75): near Thi Vai, Nha Be, and Long Tau rivers. Although the same exposure level was found (medium-high), each area has its own characteristics: (i) Thi Vai river upstream area: including Long Tho (Nhon Trach district), Long Phuoc, Phuoc Thai, Tan Hiep, Phuoc Binh (Long Thanh district), has relatively high salinity (20$25 \%$ ) but stable salinity fluctuation (1-3\%o); (ii) Nha Be river area: including Phu Huu, Phu Dong (Nhon Trach district), has medium-high salinity (the highest one is about 10-15\%o) and salinity fluctuation (around 7.5-12\%o).

The medium-low exposure region (25-50): divided into 02 regions: (i) Mainly located in Dong Nai river downstream (above the confluence with Saigon river), including Dai
Phuoc, Phu Thanh, Long Tan and Phu Hoi, Hiep Phuoc (Nhon Trach district), have been affected by salinity of Dong Nai river. (ii) Located between Dong Mon and Thi Vai river basins, including Binh Son, Suoi Trau, Cam Duong (Long Thanh district), have been affected by the flows of both basins.

The low exposure region $(<25)$ : including the entire of Bien Hoa city, most of Long Thanh district (excepting 4 wards with medium-high exposure -Long Phuoc, Phuoc Thai, Tan Hiep, Phuoc Binh), and Phuoc Thien (Nhon Trach district), have mainly been affected by salinity of part 4 of Dong Nai river, Buong river, and Thi Vai river upstream.

Considering $\mathrm{E}$ index in district/city scope, Bien Hoa city (12.07-20.84) and Long Thanh district (23.96-24.82) had low exposure level to SI while medium-high (62.55-65.26) at Nhon Trach district.

Figure 6 shows the total E index to SI in the context of CC in 2020 and 2030. Overall, although the level of exposure to SI tends to increase over time and under $\mathrm{CC}$ scenarios, the differences are not significant due to relatively short calculation period, effects of $\mathrm{CC}$ and sea level rise to SI thereby are not really clear as compared to the current situation. 


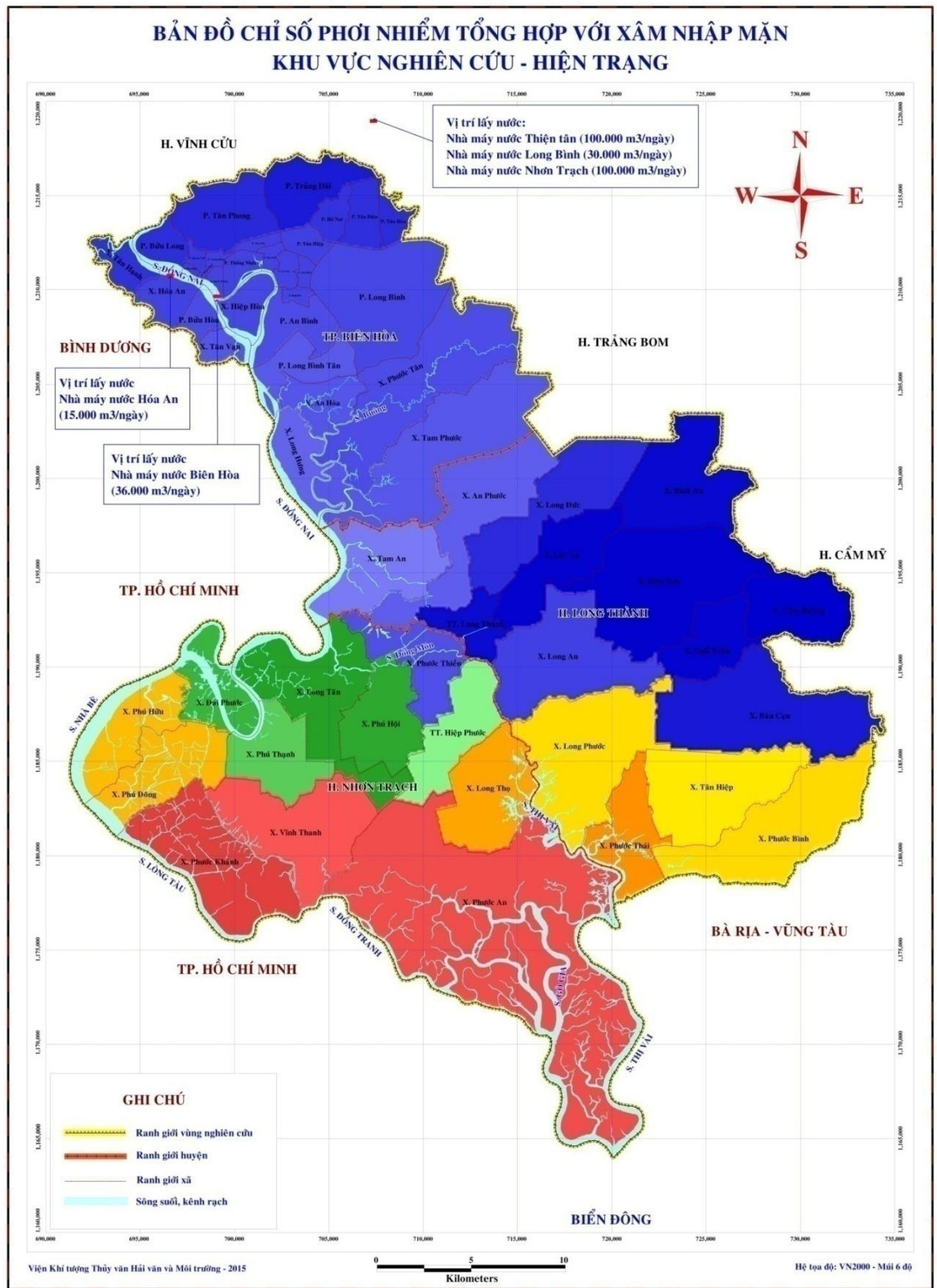

Fig. 5. Map of total exposure to SI (current) 


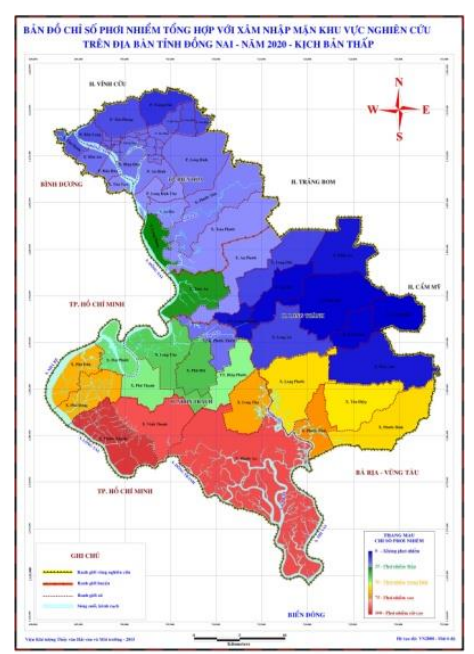

(A)

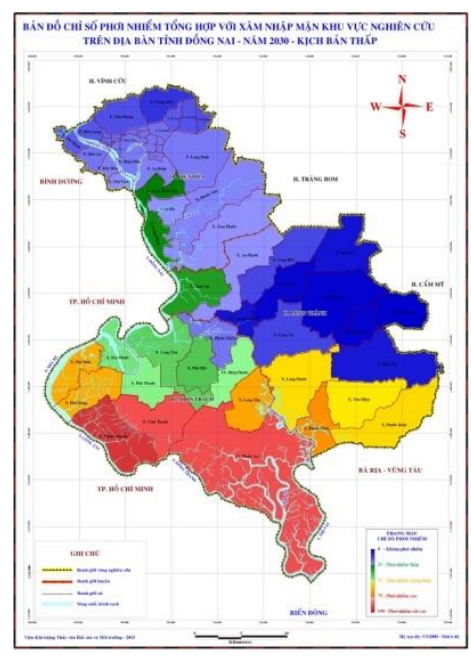

(D)

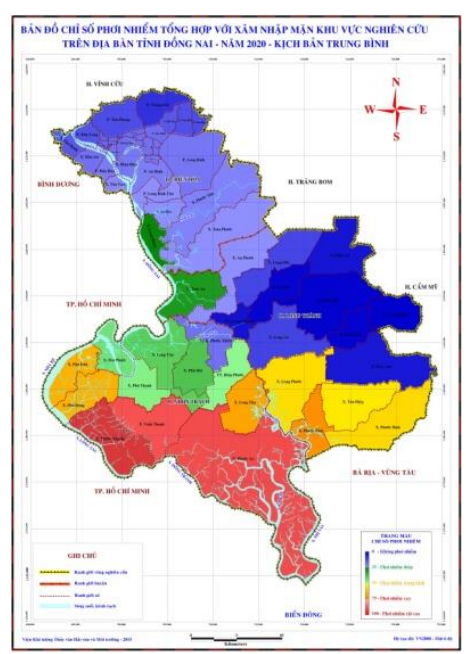

(B)

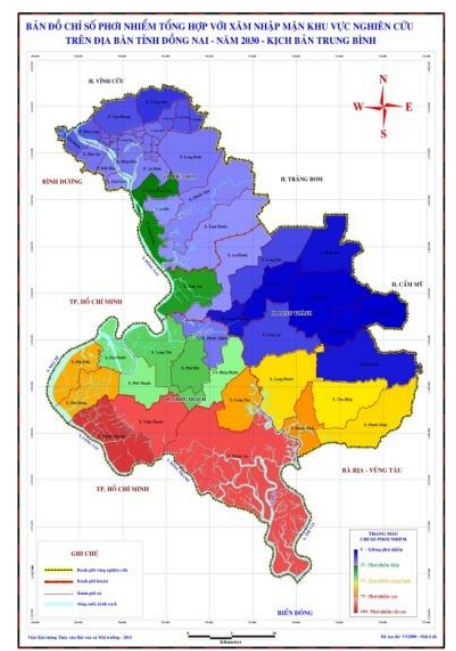

(E)

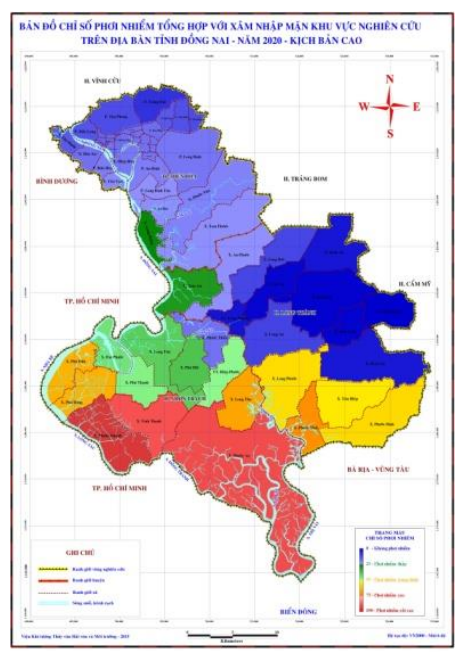

(C)

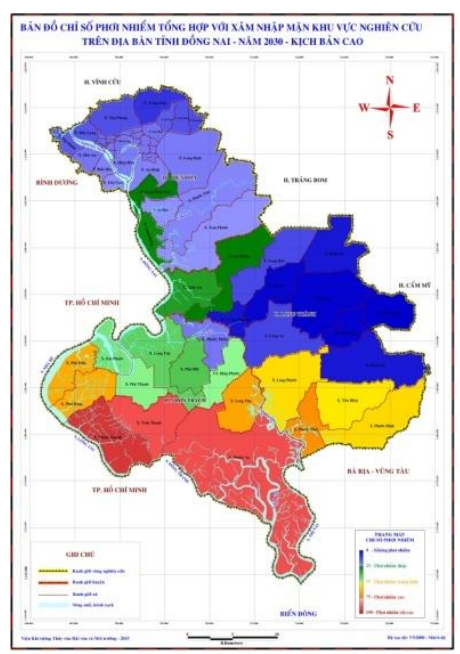

(F)

Fig. 6. Map of total E index to SI: (A) 2020-B1; (B) 2020-B2; (C) 2020-A1FI;

(D) 2030-B1; (E) 2030-B2; (F) 2030-A1FI

\section{CONCLUSION}

The study aimed to assess the exposure level to SI in the context of CC at Dong Nai province to 2030. Results showed that (i) The high exposure region (E>75): near Long Tau, Dong Tranh, and Go Gia rivers, and Thi Vai River downstream; (ii) The medium-high exposure region (E from 50-75): upstream of Thi Vai river, Nha Be, and Long Tau rivers; (iii) The mediumlow exposure region (25-50): Dong Nai river downstream (above the confluence with Saigon river about $10 \mathrm{~km}$ ) and the area between Dong Mon and Thi Vai rivers; (iv) The low exposure region $(<25)$ : includes the entire of Bien Hoa city and most of Long Thanh district that are near part 4 of Dong Nai river, Buong river and Thi Vai river upstream.

Besides, E index to SI tends to increase over the time $(2020,2030)$ and under CC scenarios.

\section{Trang 262}


However, the differences are relatively small among calculated scenarios and periods: the current exposure level to SI at Bien Hoa, Long Thanh, Nhon Trach are 12,08, 39.18, and 62.57, respectively; these values in 2030 would be
20.67-20.86, 42.16-42.33, and 65.22-65.28, respectively. Thereby, it could be inferred that effects of CC and sea level rise to exposure levels to SI at Dong Nai province are not really clear in the period 2014-2030.

\section{Đánh giá mức độ phơi nhiễm với xâm nhập mặn trong bối cảnh biến đổi khí hậu tại tỉnh Đồng Nai đến năm 2030}

- Lê Ngọc Tuấn

Trường Đại học Khoa học Tự nhiên, ĐHQG-HCM

- Trần Xuân Hoàng

Viện Khí tượng Thủy văn Hải văn và Môi trường

\section{TÓM TẮT}

Nghiên cứu nhằm muc tiêu đánh giá mức độ phoi nhiếm (E) với xâm nhập mặn (XNM) trong bối cảnh biến đổi khí hậu (BĐKH) tại tỉnh Đồng Nai đến năm 2030, phục vu đánh giá tính dễ bi tổn thuoong do hiện tuoơng này. Khu vục nghiên cứu bao gồm 57 xã phường trên địa bàn Tp. Biên Hòa, Huyện Long Thành và Huyện Nhơn Trach- nhũng noi đang xảy ra và có nguy co $X N M$. Kết quả tính toán hiện trạng cho thấy (i) Vùng phơi nhiếm cao (chỉ số E trên 75): khu vực gần sông Lòng Tàu, Đồng Tranh, Gò Gia và ha luu sông Thị Vải. (ii) Vùng phoi nhiễm trung bình cao (chi số E tù 50 - 75): khu vưc thuợng luu sông Thị Vải, sông Nhà Bè và sông Lòng Tàu. (iii) Vùng phoi nhiễm trung bình thấp (chi số E tù 25-50): khu vưc sông Đồng Nai phía trên hợp luu với sông Sài Gòn khoảng $10 \mathrm{~km}$ và khu vực

giũa sông Đồng Môn và sông Thị Vải. (iv) Vùng phoi nhiễm thấp (chi số E duoói 25): Toàn bộ thành phố Biên Hòa, một phần huyện Long Thành vị trí gần sông Buông, đoạn 4 sông Đồng Nai và thuợng nguồn sông Thị Vải. Mức độ phơi nhiếm có xu thế tăng theo thời gian (2020, 2030) và theo các kịch bản BĐKH. Chênh lệch chỉ số $E$ giũa hiện trạng và năm 2030 tuoong đối nhỏ: 8,6; 1,96 và 2,71 tuoong úng tại Biên Hòa, Long Thành và Nhon Trạch. Nhu vậy, có thể thấy ảnh hương của BĐKH và nước biển dâng đến mức độ phoi nhiễm với XNM chua thực sụ rõ nét trong khoảng thờ gian 2014-2030. Tuy nhiên, sụ gia tăng chỉ số phoi nhiễm phần nào thể hiện nhũng thách thức đối với chính quyền địa phuoong và cộng đồng dân cu trong công tác ứng phó với $X N M$ và $B \oplus K H$.

Tù khóa: xâm nhập mặn, biến đổi khí hậu, chi số phoi nhiễm

\section{REFERENCES}

[1]. V.D. Hoang, H.T. Tran, One-dimensional and two-dimensional hydrodynamic modeling for salinization downstream forecast in Ma River, Journal of Hydrometeorology, 645, 1-6 (2014).
[2]. Q.D. Tran, H.T. Nguyen, L. Kanchit, Simulation of saltwater intrusion in Mekong Delta under the impacts of sea level rise and upstream flow decline, Journal of Science, 21b, 141-150 (2012). 
[3]. T.B. Nguyen, H. Lam, S.P. Thach, Vulnerability assessment with involvement: salinization in the Mekong Delta, Journal of Science, 24b, 229-239 (2012).

[4]. T.D. Vo, Assessing vulnerability due to saltwater intrusion to agriculture in coastal area in Tra Vinh, Journal of Science and Technology Tra Vinh province, 02, 24-33, (2014).

[5]. H.H. Vu, H.D. Luong, Research, forecast trend saltwater intrusion due to sea level rise for estuaries on North Coast, Journal of Water resources and Environmental Engineering, 27, 67-78 (2009).

[6]. A.N. Nguyen, T.L. Do, Impacts of upstream works (Tri An, Thac Mo, Phuoc Hoa, Dau Tieng reservoirs) to downstream areas of Saigon - Dong Nai River. State Scientific Research Project, 1995.

[7]. T.L. Do et al, The study on integrated using the water in Dau Tieng reservoir as supplement of Phuoc Hoa reservoir, Southern Institute of Water Resources Research, 2005.

[8]. M.T. Lam, Study and proposed feasible and suitable model for organization to coordinate the implementation of environmental protection projects in Dong Nai river basin, Department of Natural Resource and Environment, Ho Chi Minh City, 2006.

[9]. V.N. Dau, Computing saltwater intrusion in Dong Nai river basin, Journal of Geology, 2007.

[10]. L.N. Tuan, Studying effects of saltwater intrusion in the context of climate change in Dong Nai province and proposing management solutions, Department of Science and Technology, Dong Nai province, 2016. 